\title{
Effect of Thinning and Harvest Type on Storage and Losses of Phosphorous in Pinus taeda L. Plantations in Subtropical Argentina
}

\author{
Rodolfo Andrés Martiarena, ${ }^{1}$ Jorge Luis Frangi, ${ }^{2}$ Martín Alcides Pinazo, ${ }^{1}$ \\ Alejandra Von Wallis, ${ }^{1}$ and Roberto Antonio Fernández ${ }^{1}$ \\ ${ }^{1}$ Estación Experimental Agropecuaria Montecarlo, INTA Avendia El Libertador 2472, 3384 Montecarlo, Misiones, Argentina
}

${ }^{2}$ LISEA, Universidad Nacional de La Plata, CC 31, 1900 La Plata, Argentina

Correspondence should be addressed to Rodolfo Andrés Martiarena, ramartiarena@montecarlo.inta.gov.ar

Received 30 November 2010; Accepted 23 March 2011

Academic Editor: Philip Comeau

Copyright (C) 2011 Rodolfo Andrés Martiarena et al. This is an open access article distributed under the Creative Commons Attribution License, which permits unrestricted use, distribution, and reproduction in any medium, provided the original work is properly cited.

\begin{abstract}
The aim of this study was to evaluate the effect of thinning intensity and different harvest types on ecosystem P conservation in 20-year-old Pinus taeda plantation ecosystems at Misiones province, Argentina. The plantation was established in 1985, thinned at three intensities - 0,33 , and $66 \%$ of basal area of control plots removed by thinning —and harvested in 2005. The nutrient content at harvest was determined for tree, shrub, and herb layers, the forest floor and upper mineral soil. Two harvest types were simulated: stem only and whole tree. Total $\mathrm{P}$ content was $56.8,46.8$, and $38.6 \mathrm{~kg} \cdot \mathrm{ha}^{-1}$ for 0 , 33, and $66 \%$ thinning, respectively. Total P exported by harvest was different among treatments, the highest at $0 \%$ thinning treatment. Phosphorus stability index values indicated that the $\mathrm{P}$ most conservative management option is $66 \%$ thinning, harvest of stem only and retention of forest floor, understory, and harvest residues.
\end{abstract}

\section{Introduction}

Pinus taeda L. (loblolly pine) is the most widely planted tree species in Argentina [1]. Misiones, with a subtropical humid climate, is the province having the largest planted area with 300,000 ha [2]. Plantations are established mostly on deep red soils of the order Ultisols [3] where the main fertility problems are associated with low availability of $\mathrm{P}$ and $\mathrm{K}$ $[4,5]$.

Thinning reduces stand density favoring dominant trees and those with better form, increases the growth rate of retained trees, and results in stands with uniform tree diameters. These are important features in managing fastgrowing plantations [6] and providing the increase of the remnant stand basal area to obtain more volume of quality wood at the end of the rotation $[7,8]$.

Thinning also influences ecosystem development [9], including modifying the availability and use of light, nutrients, and water for trees [10] and also affecting the understory
[11]. Despite the fact that the understory represents a small fraction of total biomass, dependent on plantation basal area [12], it may act as an important nutrient repository in the plantation ecosystem [13]. This is supported by observations which show differences in ecosystem nutrient content between unthinned and thinned plots [14] at the end of a rotation.

Intensively thinned plots have higher sun energy inputs to forest floor, modifying site conditions for decomposers and speeding up decomposition [15-21]. The result is a reduction of organic matter accumulated on the forest floor. Harvesting causes the greatest nutrient losses [22] and can change the $\mathrm{C}$ balance [23] including changes in decomposition conditions. Additionally, nutrient losses can increase with inappropriate management of plant residues during site preparation for a new plantation [24]. These losses affect the remnant nutrient content [25] and nutrition of pines [26] because soils cannot supply the high-nutrientdemanding fast-growing species [27], and, consequently, 
the productive capacity of the site diminishes during the following several rotations [28].

Nutrient export at harvest of high-density 20-yearold P. taeda plantations at Misiones results in plantation stability index values that indicate P deficiencies after 1.2 rotations [25]. This result suggests that nutrient management decisions are crucial to sustain the productive capacity of sites during consecutive rotations.

In Misiones, unthinned 15-year-old $P$. taeda stands can accumulate a maximum of $518 \mathrm{~m}^{3} \cdot \mathrm{ha}^{-1}$ (stem wood + stem bark) in trees of $24.4 \mathrm{~cm}$ mean DBH. Intense thinning (66\% of basal area) diminishes total volume (to $433 \mathrm{~m}^{3} \cdot \mathrm{ha}^{-1}$ ) improving product quality through mean $\mathrm{DBH}$ increase to $46.1 \mathrm{~cm}[29]$.

In Misiones, the first rotation of Pinus species were established on high productivity sites [30]. At present, plantations in these sites are finishing the second rotation, and, therefore there is a need for techniques that can sustain the productivity of these soils and the expression of the potential high growth of the new pine type obtained through genetic improvement [31].

The objective of this study was to evaluate the effect of three thinning intensities and two different harvest types on phosphorus (P) conservation in 20-year-old Pinus taeda plantations.

\section{Materials and Methods}

2.1. Site and Stand Description. Field work was done in a private estate located in the province of Misiones, Argentina $\left(25^{\circ} 59^{\prime} \mathrm{S}, 54^{\circ} 24^{\prime} \mathrm{W}\right)$. Soil is a Kandiudult [3], a red soil with $a>2 \mathrm{~m}$ depth profile, a sequence of horizons A-Bt-C, without stoniness or big rock fragments, moderate permeability, and well drained. Mean annual temperature is $21^{\circ} \mathrm{C}$, and the precipitation regime is isohydric with $c a .2000 \mathrm{~mm} \cdot \mathrm{y}^{-1}$ [32].

P. taeda (Marion origin) was established using $1644 \mathrm{pl}$. $\mathrm{ha}^{-1}$ in 1985. In 1991, the plantation was thinned reducing the stand density to $894 \mathrm{pl} \cdot \mathrm{ha}^{-1}$. In 1993, an intensity thinning assay was installed using a randomized complete block experimental design with 3 blocks and 3 low-thinning treatments: control $(0 \%)$, intermediate intensity $(33 \%)$, and strong intensity $(66 \%)$ for the basal area of control (29.2, $40.8,46.6$, and $47.2 \mathrm{~m}^{2} \cdot \mathrm{ha}^{-1}$ at $8,12,16$, and $20 \mathrm{y}$, resp.). The thinning from below treatments were repeated in 1997 and 2001, leaving plant canopy residues on site and harvesting the stems. The $\mathrm{P}$ in stems, exported during thinning, was 3.3 and $5.3 \mathrm{~kg} \cdot \mathrm{ha}^{-1}$, respectively, for 33 and $66 \%$ thinning intensity. The final size of each of the 9 plots measured was $806 \mathrm{~m} 2$. In 2005, harvest was done in plots with a density of 711,364 , and $122 \mathrm{pl} \cdot \mathrm{ha}^{-1}$ for the thinning treatments 0 , 33 and $66 \%$, respectively, with a mean diameter at breast height $(\mathrm{DBH})$ of $28.7,34.6$, and $45.9 \mathrm{~cm}$, respectively. Each harvested tree was inventoried and DBH measured with callipers and height with hypsometers.

Phosphorus content was calculated for each layer (arboreal, shrubs, and herbaceous), the forest floor and the mineral soil at each treatment plot.

The understory of un-thinned plots was mainly of Gramineae with dominance of Olyra latifolia L. Additionally, there were some Blechnum brasiliense Desv. ferns. Thinned plots with a reduction of $66 \%$ had a heliophilous grass lower strata (Paspalum sp.) and an upper understory mainly with Setaria poiretiana (Schult) Kunth, Cecropia pachystachya Trécul young trees and lianes of the genera Mikania.

2.2. Aboveground Biomass. The weight of trees was obtained by dimensional analysis [33]. A total of 45 trees were felled, 15 at each treatment, 5 per plot replicate. Trees were separated into the following compartments: stem (without bark), stembark, branches $>5 \mathrm{~cm}$ diameter, branches $<5 \mathrm{~cm}$ diameter, dead branches, leaves, and cones. The tree trunk length and diameter were measured in total and by sections to obtain volume. The most frequent section length was $3.5 \mathrm{~m}$. However, the lower sections with wider diameters were $4.3 \mathrm{~m}$ according to commercial product destination. Stem biomass per tree was calculated multiplying volume per wood density of different sections and adding them. Wood density was determined by the volumetric method employing a modified version of IRAM 9544. We used wood probes of $2 \times 2 \times$ $(\mathrm{X}) \mathrm{cm}$ where the height $(\mathrm{X})$ of the probe varied according to the size of the cross-section sample units obtained in the field for this purpose. Sample units were obtained from each of the trunk sections. A total of 2700 probes were employed with around 60 probes per tree from axial and longitudinal positions. The probes were saturated with water and its volume determined according to the Archimedes principle submerging the probes in distilled water into precipitation flasks and employing a precision balance. Finally, the probes were dried in an oven at $100 \pm 3^{\circ} \mathrm{C}$ and the density was determined as the quotient dry weight/volume. Bark dry weight was calculated taking into account its mass percentage in different stem sections. Branches, needles, and cones were separated and weighted fresh in the field. Samples of these compartments were obtained and dried at $70^{\circ} \mathrm{C}$ before weighing. Dry weight/fresh weight ratios were applied to field obtained fresh weights to obtain the dry weight of each felled tree compartment. Double-logarithmic regressions were developed $(\ln \mathrm{B}=\mathrm{a}+\mathrm{b} * \ln \mathrm{DBH})$ for each tree compartment. Later, they were applied to each inventoried tree individual to estimate the aboveground tree layer biomass.

Aboveground biomass of shrub layer was harvested in 90-2 $\mathrm{m}^{2}$ quadrats, 10 per each one of the 9 plots of trees. Shrubs were separated into leaves and woody compartments. The aboveground biomass of the herbaceous layer was harvested in $90-1 \mathrm{~m}^{2}$ quadrats, 10 per each one of the 9 plots of trees. Shrub and herbaceous compartments were dried at $70^{\circ} \mathrm{C}$ before weighing.

2.3. Forest Floor Necromass. Forest floor litter was collected in $90-0.25 \mathrm{~m}^{2}$ quadrats, 10 per each of the 9 plots of trees. Fine litter was collected in L and $\mathrm{H}+\mathrm{F}$ layers (sensu Hesselman 1926 cited by Pritchett, [34]). Woody detritus was also collected as a third compartment. All samples were dried at $70^{\circ} \mathrm{C}$ to constant weight.

2.4. Soil Sampling. One composite sample formed by 8 subsamples was obtained at each plot from horizon A $(0-10 \mathrm{~cm})$ 
and BA $(10-30 \mathrm{~cm})$, respectively. Five single samples per plot were collected from horizon B $(30-60 \mathrm{~cm})$ [35].

Bulk density of each soil horizon was determined by the cylinder method [36]. Undisturbed soil samples were taken with steel cylinders of $92,37 \mathrm{~cm}^{3}$ volume and dried at $103 \pm 2{ }^{\circ} \mathrm{C}$ to constant weight. Bulk density was calculated as the dry weight/volume ratio. We used 8 single samples from horizon A and BA and 5 samples from horizon B [37].

2.5. Chemical Analysis and P Content of Plants and Soil. Tree biomass samples were obtained from each plant: for the small compartments, aliquots were obtained from the total of the compartment and fragmented when woody and hard (e.g., cones), and for the trunk and big branches aliquots from different diameter, sections were mixed without a precise proportional mass weighting and fragmented to small chips. The dried herbs and shrubs were homogenized, and aliquots were taken for analysis. The vegetation and litter samples from each compartment were grinded in a Wiley mill using a $0.5 \mathrm{~mm}$ mesh. A total of 370 tree samples were chemically analyzed. Phosphorous extraction was done using acid digestion with a mix of nitric-percloric acid to free inorganic and organic P. Phosphorous concentration was determined through induced plasma emission spectrometry using an ICP-AES" [38]. Phosphorus content at each compartment, layer, and plot was obtained multiplying the biomass or necromass for the mean $\mathrm{P}$ concentration of the respective compartment.

Available $\mathrm{P}$ on the mineral soil horizons was determined by Bray and Kurtz method [39]. Phosphorus content to $60 \mathrm{~cm}$ depth was calculated as the sum of the products of bulk density per $\mathrm{P}$ concentration at each soil horizons.

2.6. Phosphorus Exports and Indices. To estimate $\mathrm{P}$ exports at final harvest of both types, the biomass and $\mathrm{P}$ mineral mass (equal to $\mathrm{P}$ content in the respective biomass) from the involved compartments were employed: (1) stem only (SO): sum of contents in stem + stembark of tree layer and (2) whole tree (WT): sum of contents in all aboveground compartments of tree layer.

For both harvest types, the phosphorus export index (EI) was calculated as the harvested biomass/P mineralmass ratio [40]. The nutrient stability index of plantation (SIP) was calculated as the ratio of the exported $\mathrm{P}$ content/soil available P content [41]. Two calculations were applied considering different storages of $\mathrm{P}$ immediately available to plants: option (1): Mineral soil available P and option (2): Sum of mineral soil available $\mathrm{P}$, plus $\mathrm{P}$ in forest floor, plus $\mathrm{P}$ in understory biomass and in harvest residues of tree layer.

2.7. Statistics. The means of biomass of compartments and layers, necromass of forest floor compartments, soil horizon bulk density, and $\mathrm{P}$ concentration and content of layers of vegetation, forest floor and mineral soil from treatments, were compared through ANOVA. When differences were significant, treatments means were compared with the Tukey test. In both analyses, the significance level used was $95 \%$ [42]. We report probability results into three categories: $P<$
Table 1: Content of $\mathrm{P}\left(\mathrm{kg} \cdot \mathrm{ha}^{-1}\right)$ and ecosystem total percentage (between brackets) according to thinning intensity.

\begin{tabular}{lccc}
\hline Compartment & \multicolumn{3}{c}{ Treatment (\% thinned) } \\
& $0 \%$ & $33 \%$ & $66 \%$ \\
\hline Tree layer & $40.1(70.6)^{\mathrm{a}}$ & $31.6(67.4)^{\mathrm{b}}$ & $21.2(54.9)^{\mathrm{c}}$ \\
Shrub layer & $0.17(0.3)^{\mathrm{b}}$ & $0.87(1.9)^{\mathrm{b}}$ & $4.55(11.8)^{\mathrm{a}}$ \\
Herbaceous layer & $1.69(3.0)^{\mathrm{a}}$ & $1.70(3.6)^{\mathrm{a}}$ & $1.73(4.5)^{\mathrm{a}}$ \\
Forest floor & $8.00(14.1)^{\mathrm{a}}$ & $5.79(12.4)^{\mathrm{a}}$ & $5.42(14.0)^{\mathrm{a}}$ \\
Soil & $6.84(12.0)^{\mathrm{a}}$ & $6.89(14.7)^{\mathrm{a}}$ & $5.73(14.8)^{\mathrm{a}}$ \\
\hline Total & $56.80(100)^{\mathrm{a}}$ & $46.85(100)^{\mathrm{b}}$ & $38.63(100)^{\mathrm{b}}$ \\
\hline
\end{tabular}

Different letters indicate significant statistical differences $(P<.05)$ among treatments.

$.01, P<.05$ (when $P>.01$ and $<.05$ ), and $P>.05$. The software used was INFOSTAT version 2010.

\section{Results}

3.1. Biomass and P Content of Vegetation Layers. Total and stem, bark and branches $<5 \mathrm{~cm}$ biomass, and mass of dead branches were significantly different $(P<.01)$ among thinning intensity treatments (Figure 1). Leaf biomass did not show significant differences among thinning treatments $(P>.05)$. A decreased trend was observed for leaf biomass when thinning intensity increased (Figure 1). Phosphorus concentration in tree compartments were not significantly different $(P>.05)$ among thinning treatments. The comparison test among compartments means (for $n=45$ trees) defined three groups in the following order: needles $>$ cones $>$ branches $<5 \mathrm{~cm}+$ stem + branches $>5 \mathrm{~cm}+$ bark + dead branches.

Phosphorous content in the tree layer was significantly different $(P<.01)$ among thinning treatments (Table 1$)$. The stem compartment accumulated the main $\mathrm{P}$ percentage with 75,73 , and $68 \%$, in 0,33 , and $66 \%$ intensity of thinning, respectively.

The shrub layer biomass was $0.26,0.70$, and $5.29 \mathrm{Mg}$. $\mathrm{ha}^{-1}$ for 0,33 , and $66 \%$ thinning, respectively. The value for $66 \%$ thinning was significantly different $(P<.05)$ from the other two. Phosphorous concentration was not different $(P>.05)$ among treatments, and consequently $\mathrm{P}$ content changed in proportion to biomass accumulation (Table 1).

The herbaceous layer biomass $(1.33,1.25$, and $1.07 \mathrm{Mg} \cdot \mathrm{ha}^{-1}$ for 0,33 , and $66 \%$ thinning, resp.) and $\mathrm{P}$ concentration $\left(1.27,1.37\right.$, and $1.61 \mathrm{mg} \cdot \mathrm{g}^{-1}$ for 0,33 , and $66 \%$ thinning, resp.) and content did not differ significantly among treatments $(P>.05$; Table 1$)$.

3.2. Phosphorous Content of Forest Floor and Mineral Soil. Forest floor necromass totaled $25.0( \pm 8.2), 18.3( \pm 5.5)$, and $16.6( \pm 4.1) \mathrm{Mg} \cdot \mathrm{ha}^{-1}$, for the 0,33 and $66 \%$ thinning, respectively, without significant differences $(P>.05)$ among treatments as also shown for the $\mathrm{P}$ concentration and content $(P>.05$; Table 1$)$. Phosphorus concentration in forest floor compartments increased top-down: fine woody detritus $(0.19,0.20$, and 0.31$)<\mathrm{L}$ layer $(0.32,0.30$, and 0.26$)<\mathrm{H}+\mathrm{F}$ 
Leaves

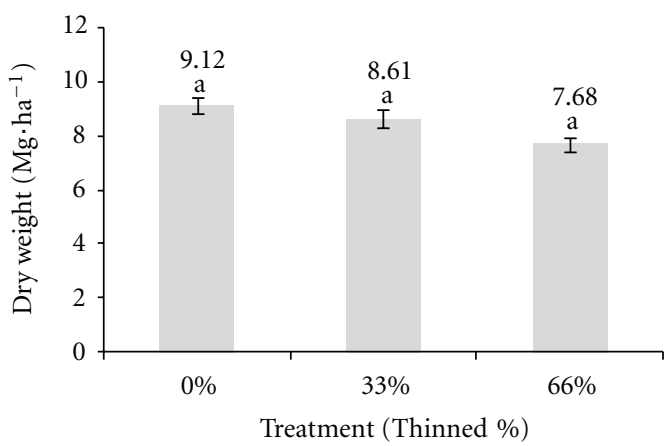

Branches $>5 \mathrm{~cm}$

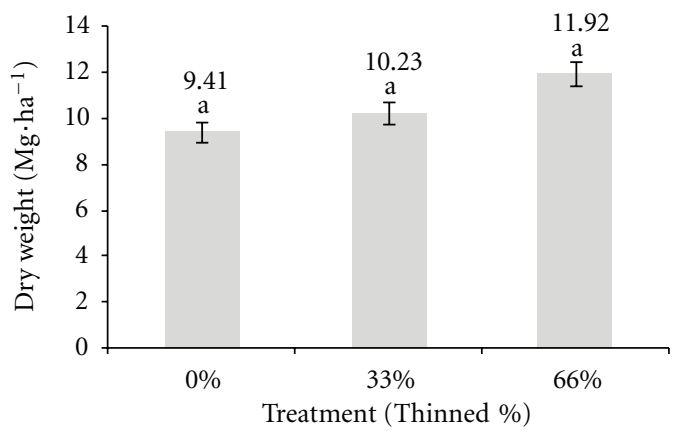

Bark

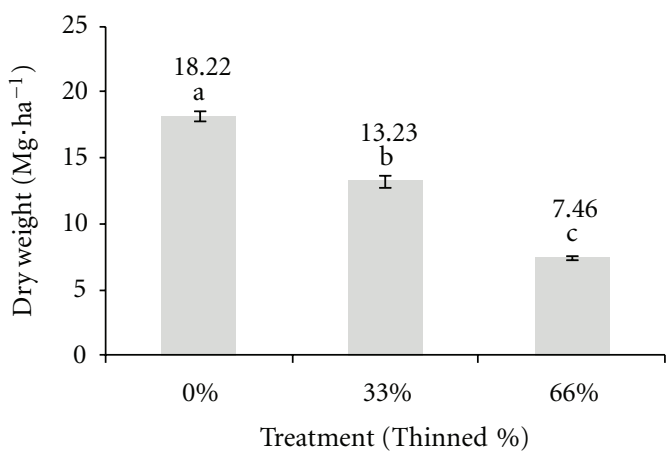

Stem

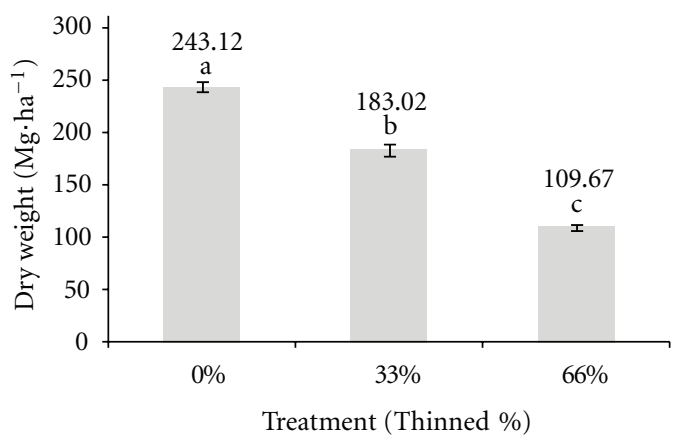

Cones

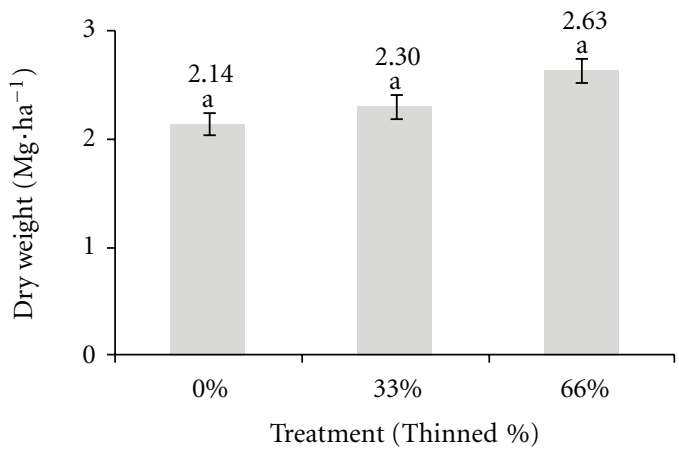

Branches $<5 \mathrm{~cm}$

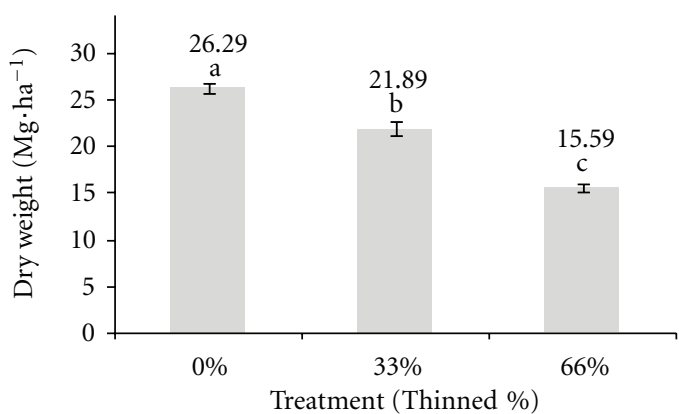

Dead branches

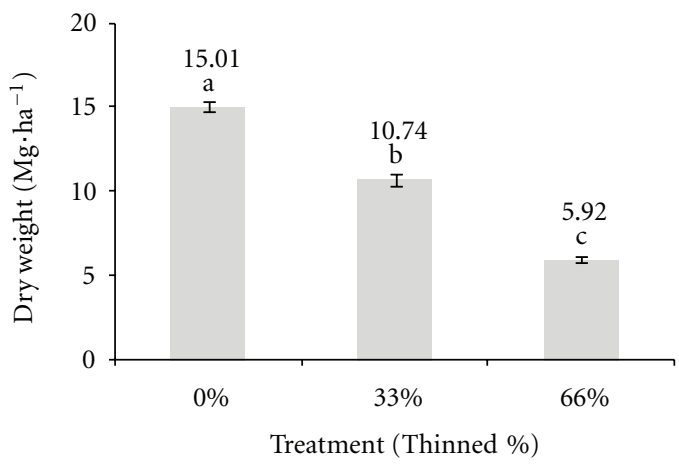

Total biomass

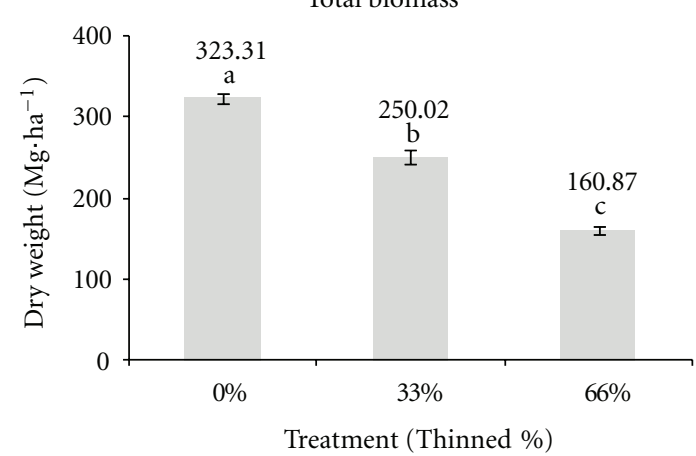

FIgURE 1: Biomass of aboveground compartments at stand level versus thinning intensity in 20-year-old Pinus taeda plantations. Different letters indicate significant differences among treatments at a 95\% probability based on Tukey's HSD test. Thin line in bar indicates standard deviation of the mean. 
TABLE 2: Bulk density (mean \pm standard deviation, in $\mathrm{g} \cdot \mathrm{cm}^{-3}$ ) of mineral soil horizons sampled at different depth intervals in plots with different thinning intensity (TI) treatments. No significant differences in bulk density were observed among treatments.

\begin{tabular}{cccc}
\hline $\begin{array}{l}\text { Soil depth interval } \\
(\mathrm{cm})\end{array}$ & \multicolumn{3}{c}{ Thinning intensity (\%) } \\
\hline \multirow{2}{*}{$0-10$} & 1.32 & 1.35 & 66 \\
& $( \pm \mathbf{0 . 0 1})$ & $( \pm \mathbf{0 . 0 7})$ & $1.30( \pm \mathbf{0 . 0 9})$ \\
& 1.26 & 1.27 & $1.35( \pm \mathbf{0 . 0 8})$ \\
$10-30$ & $( \pm \mathbf{0 . 1 1})$ & $( \pm \mathbf{0 . 0 2})$ & \\
& 1.22 & 1.29 & $1.30( \pm \mathbf{0 . 0 6})$ \\
$30-60$ & $( \pm \mathbf{0 . 0 7})$ & $( \pm \mathbf{0 . 0 4})$ & \\
\hline
\end{tabular}

layer $(0.55,0.44$, and 0.52$)$, for 0,33 , and $66 \%$ thinning, respectively. Comparing the same compartments, differences were not significant for $\mathrm{P}$ concentrations among treatments $(P>.05)$.

The mineral soil bulk density and concentration of available $\mathrm{P}$ were not different among treatments $(P>.05)$. Mean concentration of available $P$ for all treatments was 2.16, 0.83 , and $0.40 \mathrm{ppm}$ for $\mathrm{A}, \mathrm{BA}$, and $\mathrm{B}$ horizons, respectively. Available $\mathrm{P}$ content to $60 \mathrm{~cm}$ depth is reported in Table 1 and soil bulk density in Table 2 .

\subsection{Phosphorous Content and Management of Plantation} Ecosystem. At the end of rotation period, total ecosystem $\mathrm{P}$ content showed an inverse relationship with thinning intensity. Differences were significant $(P<.01)$ among the $66 \%$ thinned plots and the 0 and $33 \%$ thinned plots treatments (Table 1).

Understory, due to shrubs, increased its percentage of $\mathrm{P}$ storage with the increase in thinning intensity. The $\mathrm{P}$ content at $66 \%$ thinned plots was fivefold ( $16.3 \%$ of total available $\mathrm{P}$ ) of that of $0 \%$ thinned plots (control treatment with $3.3 \%$ of total available P; Table 1).

Phosphorous mass exported at final harvest in both harvest types (SO and WT) was different among treatments $(P<.01$ (SO and WT)). Phosphorus remaining at the site after harvest did not change significantly with thinning intensity $(P>.05$ (SO and WT)); Table 3$)$. The harvest system WT exported $10.9,9.5$, and $8.1 \mathrm{~kg} \cdot \mathrm{ha}^{-1}$ more $\mathrm{P}$ than its similarly thinned from harvest system $\mathrm{SO}$, respectively, for the thinning treatments 0,33 , and $66 \%$, showing significant differences for the three treatments $(P<.01)$.

The highest wood biomass harvested per unit $\mathrm{P}$ exported was obtained with the SO harvest type and a thinning intensity of $66 \%$, as shown by EI in Table 4 . The most P conservative scenario for a site was obtained when $66 \%$ thinning, and SO harvest was combined with the retention in the ground of organic debris from forest floor, damaged understory, and harvest residues as shown in option (2) of SIP.

\section{Discussion}

4.1. Biomass and P Content in the Plantation Ecosystem. The higher density of un-thinned (control) plantation favored the increase of intraspecific competition. As a consequence, trees in non-thinned treatment near rotation end had (1) a lower mean DBH $(28.7,34.8$, and $45.9 \mathrm{~cm}$ in 0,33 , and $66 \%$ intensity of thinning, resp.), (2) suppressed individuals, (3) a reduced tree canopy size, and (4) a lower foliar biomass proportion $(2.6,3.7$, and $4.3 \%$ in 0,33 , and $66 \%$ intensity of thinning, resp.). Similar results were reported elsewhere $[43,44]$. For example, a 17-year-old P. taeda plantation from a West Gulf Coastal Plain site in Louisiana, that was thinned $c a .15 \%$ of BA at 7 and $14 \mathrm{y}$, increased the plantation mean $\mathrm{DBH}$ and length of the canopy suggesting that stand density management is important to induce vigor and potential growth of trees [44]. Moreover, foliar percentage in canopy was higher in thinned plantations with a proportional increase of $4.6 \%$ at 17 -year-old [44]. In another site, with a different environment and lower growth rates, a plantation thinned $40 \%$ of BA significantly increased its biomass and canopy components with respect to control, $12 \mathrm{y}$ after thinning [7].

On the opposite side, the lower competition in intermediate and strongly thinned plots (33 and 66\%) allowed for a better expression of the hereditary plant architecture of the species with a greater development of individual canopy, a larger mean DBH of trees near final cut time and the highest biomass of plantation canopy. Several studies coincide in these trends [44-47]. For instance, a summary of 7 research studies about the production dynamics of intensively managed $P$. taeda from Southern USA reported thinning as one of the best strategies to increase productivity and monetary value of stands [47]. In this sense, thinned plots showed features found in non-full-stocked forest sites $[48,49]$. Relative to $\mathrm{P}$, different $\mathrm{P}$ contents among thinned plots and control have been reported in other studies [14].

Although it is not significant, the consistent trend toward a lower leaf biomass (and then LAI) with thinning increase suggests a lower capacity of strongly thinned non-fullstocked stands to capture available sunlight at rotation end as found in another study [47]. From a silvicultural point of view, $66 \%$ thinning may be excessive for wood production because it results in incomplete use of available resources and lower yields [29]. At the other extreme, the highest proportion of dead branches observed at $0 \%$ thinning may be due to a lower half-life, early mortality, and temporal delay of branch fall at tree canopy due to growth under strong competition conditions. Decreased canopy parameters in un-thinned plantations have been reported elsewhere [43, 44].

Phosphorus concentration values found in aboveground tree biomass compartments were similar to other reported in Misiones [50]. Accordingly, P concentration accomplished through the same concentration trend: leaves, fine branches, and fruits had higher P concentration than stem and coarse branches as generally observed in woody plants $[17,25,51-$ 53]. However, $P$ concentration in leaves from this study was lower than in the same compartment and species reported for different sites in the USA [54]. This may be related to low $P$ availability in soils of the region herein studied [5], taking into account that thinning intensity did not affect soil density (Table 2), and, consequently, P content was similar among 
TABLE 3: Content of P exported and remaining in the ecosystem after the final harvest considering stem-only harvest (SO) and whole-tree harvest (WT) types according to thinning intensity (in \% of control basal area).

\begin{tabular}{|c|c|c|c|c|c|}
\hline & & \multirow{2}{*}{$\begin{array}{c}\text { Content of } \mathrm{P} \\
\left(\mathrm{kg} \cdot \mathrm{ha}^{-1}\right)\end{array}$} & \multicolumn{3}{|c|}{ Thinning treatment } \\
\hline & & & $0 \%$ thinned & $33 \%$ thinned & $66 \%$ thinned \\
\hline \multirow{4}{*}{ Harvest type } & \multirow{2}{*}{ SO } & Exported at harvest & $29.24^{\mathrm{a}}(\mathrm{B})$ & $22.03^{\mathrm{b}}(\mathrm{B})$ & $13.19^{c}(B)$ \\
\hline & & Remaining at ecosystem & $27.56^{\mathrm{a}}(\mathrm{A})$ & $24.78^{\mathrm{a}}(\mathrm{A})$ & $25.49^{\mathrm{a}}(\mathrm{A})$ \\
\hline & \multirow{2}{*}{ WT } & Exported at harvest & $40.10^{\mathrm{a}}(\mathrm{A})$ & $31.57^{\mathrm{b}}(\mathrm{A})$ & $21.27^{\mathrm{c}}(\mathrm{A})$ \\
\hline & & Remaining at ecosystem & $16.70^{\mathrm{a}}(\mathrm{B})$ & $15.26^{\mathrm{a}}(\mathrm{B})$ & $17.43^{\mathrm{a}}(\mathrm{B})$ \\
\hline
\end{tabular}

Different lowercase letters $(\mathrm{a}, \mathrm{b}, \mathrm{c})$ indicate significant differences $(P<.05)$ among masses of $\mathrm{P}$ exported or remaining, among the thinning treatment for the same harvest type. Uppercase letters $((\mathrm{A}),(\mathrm{B}))$ between brackets indicate significant differences $(P<.05)$ among masses of $\mathrm{P}$ exported or remaining, among harvest types for the same thinning treatment.

TABLE 4: Phosphorous export index (EI) and phosphorous stability index of plantations (SIP) for 20-year-old Pinus taeda, for two final cutting harvest scenarios (SO and WT).

\begin{tabular}{lcccl}
\hline $\begin{array}{l}\text { Harvest } \\
\text { scenario }\end{array}$ & $\begin{array}{c}\text { Treatment } \\
\text { (\% thinning) }\end{array}$ & EI & \multicolumn{2}{c}{ SIP } \\
\hline \multirow{2}{*}{ SO } & 0 & 8.64 & 4.42 & 1.08 \\
& 33 & 9.38 & 3.34 & 0.90 \\
& 66 & 11.7 & 2.15 & 0.50 \\
\hline \multirow{2}{*}{ WT } & 0 & 7.77 & 6.08 & 2.49 \\
& 33 & 8.18 & 4.84 & 2.19 \\
& 66 & 9.98 & 3.38 & 1.11 \\
\hline
\end{tabular}

Option 1: includes available P in mineral soil; Option 2: includes available $\mathrm{P}$ in mineral soil, plus $\mathrm{P}$ contained in organic debris from the forest floor, understory, and harvest residues.

treatments. Low $\mathrm{P}$ concentration in leaves and branches $<5 \mathrm{~cm}$ influenced $\mathrm{P}$ content in both compartments with an added maximum of $29 \%$ of total P content in the tree layer. Other studies report that both may sum up to $50 \%$ of total P content in trees [18].

Pinus taeda bark had 2 to $3 \%$ of $\mathrm{P}$ content in aboveground tree biomass, a value considered low for this compartment. Stembark separation from stem-only harvest type for leaving bark in the field is considered an important nutrient conservative practice for those species with a high nutrient content in bark [55]. In the present study, $\mathrm{P}$ content in stembark was $4.1,4.5$, and $3.3 \%$ of total $\mathrm{P}$ mass in stem only for $0 \%, 33 \%$, and $66 \%$ thinning treatments, respectively. Then, avoiding bark retention at site appears to be a small $\mathrm{P}$ loss with harvest export [49]. Notwithstanding, it may be not left aside the bark role-as mulch and source of nutrients to the soil-for ecological management considering an adequate use of harvest residues and the relative contribution of bark P return with respect to the soil available P.

Creating canopy gaps through thinning induces changes in growth and composition of understory [11, 56, 57]. We found that shrubs benefited most from intense thinning as shown by the increase in shrub biomass and $\mathrm{P}$ mineralmass with increase in thinning intensity. As mentioned earlier, higher sunlight availability for lower layers may be one of the main factors triggering understory growth [43]. The $6.3 \mathrm{~kg}$ $\mathrm{P} \cdot \mathrm{ha}^{-1}$ stored in the understory is not far from the maximum of ca. $8 \mathrm{~kg} \cdot \mathrm{ha}^{-1}$ reported in the literature [58]. Understory may be a potential source of $\mathrm{P}$ after harvest [16] by clear cutting or thinning and also a $\mathrm{P}$ sink diminishing $\mathrm{P}$ losses from ecosystem [59].

The higher necromass in the forest floor of the unthinned control was probably partially due to a lower half-life of canopy leaves. The leaf mass produced by the closed structure of these stands [60] reduces light available to plant organs in lower locations $[43,61]$, so favouring litter fall and litter accumulation in denser plantations [62]. The lower density in strongly thinned plots allows for higher energy inputs in the forest floor, and, together with other environmental variables, modifies site conditions for decomposers and stimulates faster decomposition rates [1521]. Thus, it reduces organic matter storage in the forest floor. The trend found in this study and the attributed causes are similar to those reported by other authors [63-67].

The $\mathrm{L}$ and $\mathrm{H}+\mathrm{F}$ layers are the result of several processes involved in inputs, outputs, and physical-chemical transformation of matter in the forest floor. The highest $\mathrm{P}$ concentration at $\mathrm{H}+\mathrm{F}$ layer compared to $\mathrm{L}$ layer was probably caused by nutrient immobilization by microorganisms decomposing a nutrient-poor litter. Organic matter at $\mathrm{H}+\mathrm{F}$ layer decomposed for a longer time than recent fallen material forming the L layer and, as microorganism tissues have a lower $\mathrm{C} / \mathrm{P}$ ratio than litter; they progressively change nutrient stoichiometry of the organic particlesmicroorganisms complex [68]. Other studies obtained similar results $[25,69,70]$.

Available $\mathrm{P}$ was only $0.5 \%$ of total $\mathrm{P}$ in soil, but, as total $\mathrm{P}$ to available $\mathrm{P}$ replenishment fluxes are unknown, it is not possible to infer the effect of thinning treatments in soil $\mathrm{P}$ concentration and content. Furthermore, some nutrients may be lost by lixiviation or immobilized in complex molecules or by competitors [71] after harvesting or a new plantation establishment [24]. In fact, better forestry practices should minimize the modification of sites, including the avoidance of soil nutrients losses to sustain fertility and long-term productivity.

\subsection{Impact of Management on $P$ Content of Plantation} Ecosystem. Due to the high fraction of nutrients contained in canopy, the whole tree (WT) harvest type resulted in the highest exported mass of $\mathrm{P}$ as reported for other forestry 
species $[72,73]$. As $\mathrm{P}$ is essential for plant growth and the main limiting nutrient in soils of the region [25], it is necessary to use harvest practices that minimize $\mathrm{P}$ losses with products extraction.

The percentages of $\mathrm{P}$, with respect to total $\mathrm{P}$ in the ecosystem, exported with WT harvest type, were high (71, 67 , and $55 \%$ for 0,33 , and $66 \%$ thinning, resp.), indicating that most ecosystem $\mathrm{P}$ is in trees and that the $\mathrm{P}$ percent losses depend on plantation density. The percentages of $\mathrm{P}$ were higher than those reported for another $P$. taeda plantation with lower density $\left(437 \mathrm{pl} \cdot \mathrm{ha}^{-1}\right)$ where $\mathrm{P}$ output with harvest was ca. $50 \%$ of total P [74].

Phosphorus losses occur in short periods during and immediately after harvest and depend on both harvest type and thinning intensity during rotation. The $\mathrm{P}$ mass remaining in the ecosystem depends mainly on harvest type and conservative postharvest management. Comparison of equivalent SIP among harvest types for $P$. taeda showed that nutrient export with WT harvesting is 2-3 times greater than with $\mathrm{SO}$, as has been reported elsewhere [75].

Understory plants concentrate and temporarily retain absorbed soil nutrients. Moreover, they are a source of labile organic matter able to release nutrients during decomposition. In fact, the positive impact of conserving organic matter from the understory, forest floor, and harvest residues as a source of $\mathrm{P}$ and other nutrients source was evident compared with the values of both SIP options (Table 4). The best combination of practices for more efficient use of $\mathrm{P}$ included $66 \%$ thinning intensity, harvest of stem only, and retention on site of organic matter from necromass and uncollected biomass compartments. This combination resulted in a SIP 12-times lower than the opposite most extreme combination of treatments $(0 \%$ thinning, wholetree harvest, and elimination of harvest residues).

Regardless of thinning treatment and harvest type, $\mathrm{P}$ remaining in the soil (available $\mathrm{P}$ in mineral horizons $+\mathrm{P}$ in forest floor $+\mathrm{P}$ in harvest residues) may not be sufficient to supply the needs of another rotation of the same species. However, since the index used does not consider P inputs to or outputs from the ecosystem during rotation (with the exception of those related to thinning and final harvest), we cannot accurately estimate the number of rotations that are sustainable. A previous study in Misiones identified at rotation end that $\mathrm{P}$ is one of the limiting elements in plantations of $P$. taeda [25]. The number of rotations that can be planted without nutrient replacement depends not only on tree harvests and the tolerance of the species towards soil changes but also on nutrient replenishment mechanisms of the soil and other losses not considered by the indices used in this work. If we suppose that replenishment of soil available $\mathrm{P}$ by total $\mathrm{P}$ is continuous until total $\mathrm{P}$ becomes exhausted, and taking into account that $\mathrm{P}$ is exported during thinning and harvests, the availability of $\mathrm{P}$ in the sites might be enough for 86 (SO) to 61 (WT) rotations, independently of the thinning intensity applied. This calculation demonstrates the importance of residue conservation during harvests (thinning and final) and emphasizes the need for research relating to changes in total and available $\mathrm{P}$ and the $\mathrm{P}$ cycle throughout the rotation in these stands.

\section{Conclusions}

This study demonstrates that silvicultural decisions regarding thinning intensity, harvest type, forest floor, and harvest residue conservation will influence biomass accumulation in trees and shrub understory and $\mathrm{P}$ content but will not influence $\mathrm{P}$ concentration in vegetation compartments or the capacity to sustain future rotations of Pinus taeda plantations in this region. Stem-only harvest is a better option than whole-tree harvest regarding $\mathrm{P}$ and probably other nutrients. Conservation of organic matter from the forest floor, understory, and harvest residues helps to supply $\mathrm{P}$ to soil and to reduce $\mathrm{P}$ losses. Consequently, the selection of postharvest practices to prepare land for a new plantation should include considerations on the effect on the abovementioned compartments.

Our study shows that simple and sensitive indices can be useful for evaluating nutritional stability with regard to $\mathrm{P}$ and to the selection of management practices that balance wood production and nutrient conservation.

\section{Acknowledgment}

The authors thank LIPSIA SA for local support in the estate and the permission to use their plantations for this study.

\section{References}

[1] SAGPyA, Inventario nacional de plantaciones forestales. Secretaría de Agricultura, Ganadería, Pesca y Alimentación de la Nación, Buenos Aires, Argentina, 2001, http://www.sagpya .mecon.gov.ar/new/0-0/forestacion/inventario/Inventario2 .htm.

[2] SIFIP, Sistema de información foresto-industrial provincial. Ministerio del Agro y la producción, Misiones, Argentina, 2010, http://extension.facfor.unam.edu.ar/sifip/inventario.

[3] Soil Survey Staff, Keys to Soil Taxonomy, vol. 436 of Agriculture Handbooks, NRCS, Washington, DC, USA, 10th edition, 2006.

[4] C. A. Pérez, J. F. Goya, F. Bianchini, J. L. Frangi, and R. Fernández, "Aboveground productivity and nutrient cycle in Pinus taeda L. Plantations in the north of the Misiones Province, Argentina," Interciencia, vol. 31, no. 11, pp. 794-801, 2006.

[5] L. A. Morales and S. Vazquez, "Phosphorus adsorption by acid soils from misiones (Argentina)," Ciencia del Suelo, vol. 18, no. 2, pp. 89-94, 2000.

[6] D. Pérez and M. Kanninen, "Effect of thinning on stem form and wood characteristics of teak (Tectona grandis) in a humid tropical site in Costa Rica," Silva Fennica, vol. 39, no. 2, pp. 217-225, 2005.

[7] E. Valinger, B. Elfving, and T. Mörling, "Twelve-year growth response of Scots pine to thinning and nitrogen fertilisation," Forest Ecology and Management, vol. 134, no. 1-3, pp. 45-53, 2000.

[8] L. Nutto, P. Spathelf, and I. Seling, "Management of individual tree diameter growth and implications for pruning for Brazilian Eucalyptus grandis Hill ex Maiden," Floresta, vol. 36, no. 3, pp. 397-413, 2006.

[9] V. G. Marshall, "Impacts of forest harvesting on biological processes in northern forest soils," Forest Ecology and Management, vol. 133, no. 1-2, pp. 43-60, 2000. 
[10] E. C. Burkes, R. E. Will, G. A. Barron-Gafford, R. O. Teskey, and B. Shiver, "Biomass partitioning and growth efficiency of intensively managed Pinus taeda and Pinus elliottii stands of different planting densities," Forest Science, vol. 49, no. 2, pp. 224-234, 2003.

[11] B. Marilou, C. Messier, and A. Leduc, "Understorey light profiles in temperate deciduous forests: recovery process following selection cutting," Journal of Ecology, vol. 92, no. 2, pp. 328-338, 2004.

[12] M. Herrera, J. Del Valle, and S. Orrego, "Biomasa de la vegetación herbácea y leñosa pequeña y necromasa en bosques tropicales primarios y secundarios de Colombia," in Proceedings of the Simposio Internacional Medición y Monitoreo de la Captura de C en Ecosistemas Forestales, Chile, 2001.

[13] M. R. Guariguata and R. Ostertag, "Neotropical secondary forest succession: changes in structural and functional characteristics," Forest Ecology and Management, vol. 148, no. 1-3, pp. 185-206, 2001.

[14] J. Blanco, J. Bosco Imbert, and F. Castillo, "Effects of thinning on nutrient content pools in two Pinus sylvestris forests in the western Pyrenees," Scandinavian Journal of Forest Research, vol. 21, no. 2, pp. 143-150, 2006.

[15] A. Muscolo, M. Sidari, and R. Mercurio, "Influence of gap size on organic matter decomposition, microbial biomass and nutrient cycle in Calabrian pine (Pinus laricio, Poiret) stands," Forest Ecology and Management, vol. 242, no. 2-3, pp. 412-418, 2007.

[16] M. Palviainen, Logging residues and ground vegetation in nutrient dynamics of a clear-cut boreal forest. Dissertations forestall 12. To be presented, with the permission of the Faculty of Forestry of the University of Joensuu, for public criticism in Auditorium C2 of the University, Yliopistokatu 4, Joensuu, Finland, 2005.

[17] J. Bosco Imbert, J. Blanco, and F. Castillo, "Gestión forestal y ciclos de nutrientes en el marco del cambio global," EGRAF, Sa, Madrid, Spain, Ecología de bosque mediterráneo en un mundo cambiante. Ministerio de Medio Ambiente, 2004.

[18] C. E. Prescott, "The influence of the forest canopy on nutrient cycling," Tree Physiology, vol. 22, no. 15-16, pp. 1193-1200, 2002.

[19] R. Borém and D. Ramos, "Variação estacional e topográfica de nutrientes na serapilheira de um fragmento da mata atlântica," Cerne, vol. 8, no. 2, pp. 42-59, 2002.

[20] P. Pérez Batallón, G. Ouro, A. Merino et al., "Descomposición de materia orgánica, biomasa microbiana y emisión de $\mathrm{CO}_{2}$ en un suelo forestal bajo diferentes manejos silvícolas," Edafología, vol. 5, pp. 83-93, 1998.

[21] M. M. Couteaux, P. Bottner, and B. Berg, "Litter decomposition climate and litter quality," Trends in Ecology and Evolution, vol. 10, no. 2, pp. 63-66, 1995.

[22] L. Gonçalves and V. Benedetti, Nutrição e fertilização florestal, IPEF. Instituto de Pesquisas e Estudos Florestais, Piracicaba, Sao Paulo, Brasil, 2000.

[23] L. E. Nave, E. D. Vance, C. W. Swanston, and P. S. Curtis, "Harvest impacts on soil carbon storage in temperate forests," Forest Ecology and Management, vol. 259, no. 5, pp. 857-866, 2010.

[24] R. Martiarena, A. Von Wallis, and O. Knebel, "Pérdida de nutrientes durante la cosecha y el establecimiento forestal, en un rodal de Pinus taeda en Misiones, Argentina," Revista Forestal Venezolana, vol. 53, no. 2, pp. 165-173, 2009.

[25] J. F. Goya, C. Pérez, J. L. Frangi, and R. Fernández, "Harvesting effects and residue fate on nutrient stability of Pinus taeda L. plantations," Ecologia Austral, vol. 13, no. 2, pp. 139-150, 2003.
[26] C. T. Smith, A. T. Lowe, M. F. Skinner, P. N. Beets, S. H. Schoenholtz, and S. Fang, "Response of radiata pine forests to residue management and fertilisation across a fertility gradient in New Zealand," Forest Ecology and Management, vol. 138, no. 1-3, pp. 203-223, 2000.

[27] S. S. Tutua, Z. H. Xu, T. J. Blumfield, and K. A. Bubb, "Longterm impacts of harvest residue management on nutrition, growth and productivity of an exotic pine plantation of subtropical Australia," Forest Ecology and Management, vol. 256, no. 4, pp. 741-748, 2008.

[28] A. Tiarks, M. Elliott-Smith, and R. Stagg, "Effect of logging residue management on the growth and nutrient distribution of a Pinus taeda plantation in Central Louisiana, USA," in Proceedings of the 5th Workshop on Site Management and Productivity in Tropical Plantation Forests: Impacts on Soils and Options for Management Over Successive Rotations, E. K. S. Nambiar, J. Ranger, A. Tiarks, and T. Toma, Eds., pp. 151-162, Guangzhou, China, 2003.

[29] E. Crechi, H. Fassola, R. Fernández et al., "Efecto del raleo en Pinus taeda," IDIA, vol. 21, no. 8, pp. 43-47, 2005.

[30] R. Fernández, A. Lupi, and N. Pahr, "Aptitud de las tierras para la implantación de bosques," Provincia de Misiones Yvyrareta, vol. 9, pp. 41-49, 1999.

[31] A. Lupi, M. Conti, R. Fernández et al., "Efecto de las prácticas de repoblación forestal sobre el carbono orgánico del suelo y la estabilidad de los agregados en el noreste de Argentina," Investigación Agraria: Sistemas y Recursos Forestales, vol. 16, no. 3, pp. 230-240, 2007.

[32] INTA, “Atlas de suelos de la República Argentina," Provincia de Misiones, vol. 2, pp. 111-154, 1990.

[33] R. Whittaker and G. Woodwell, "Dimension and production relations of trees and shrubs in the Brookhaven forest, New York," Journal of Ecology, vol. 56, pp. 1-25, 1968.

[34] W. Pritchet, "Suelos Forestales. Propiedades, conservación y mejoramiento," Editorial Limusa, p. 634, 1986.

[35] R. Fernández, A. Lupi, N. Pahr et al., "Técnicas de manejo de residuos de cosecha para el establecimiento forestal y su impacto sobre la condición química de los suelos rojos del noreste de Argentina," in Avances en Ingeniería Agrícola, pp. 243-248, Facultad Agronomía, UBA, Buenos Aires, Argentina, 2000.

[36] W. Forsythe, Física de Suelos. Manual de Laboratorio, IICA, Turrialba, 1975.

[37] R. Fernández, P. MacDonagh, A. Lupi et al., "Relations between soil compaction and plantation growth of a 8 yearsold Lobolly pine second rotation, in Misiones, Argentine," in Proceedings of the ASAE Annual Meeting, ASAE, St. Joseph, Mich, USA, 2002.

[38] C. Johnson and A. Ulrich, "Analytical methods for use in plant analysis," Bulletin of the University of California Agricultural Experiment Station, vol. 766, pp. 26-27, 1959.

[39] R. Bray and L. Kurtz, "Determination of total, organic and available forms of phosphorus in soil," Soil Science, vol. 59, pp. 39-45, 1945.

[40] R. Santana, N. Barros, and J. Neves, "Eficiência de utilização de nutrientes e sustentabilidade da produção em procedências de Eucalyptus grandis e E. saligna em sítios florestais do esta do de São Paulo,” Árvore, vol. 26, no. 4, pp. 447-457, 2002.

[41] H. Föllster and P. Khanna, "Dynamics of nutrient supply in plantation soil," in Management of Soil Nutrient and Water in Tropical Plantation Forest, E .K. S. Nambiar and A. G. Brown, Eds., pp. 339-378, CSIRO, Canberra, Australia, 1997. 
[42] R. Steel and J. Torrie, Principles and Procedures of Statistics. A Biometrical Approach, McGraw-Hill, New York, NY, USA, 2nd edition, 1980.

[43] S. S. Chan, D. J. Larson, K. G. Maas-Hebner, W. H. Emmingham, S. R. Johnston, and D. A. Mikowski, "Overstory and understory development in thinned and underplanted Oregon Coast Range Douglas-fir stands," Canadian Journal of Forest Research, vol. 36, no. 10, pp. 2696-2711, 2006.

[44] M. A. Sword Sayer, J. C. G. Goelz, J. L. Chambers et al., "Long-term trends in loblolly pine productivity and stand characteristics in response to thinning and fertilization in the West Gulf region," Forest Ecology and Management, vol. 192, no. 1, pp. 71-96, 2004.

[45] A. Vidal, J. Benítez, J. Rodríguez et al., "Estimación de la biomasa de copa para árboles en pie de Pinus caribaea var. caribaea en la E.F.I. La Palma de la provincia de Pinar del Río, Cuba," Quebracho, vol. 11, pp. 60-66, 2003.

[46] J. Siry, "Intensive timber management practices," in Southern Forest Resource Assessment, D. N. Wear and J. G. Greis, Eds., chapter 14, pp. 327-340, U.S. Department of Agriculture Southern Research Station, Asheville, NC, USA, 2002, Technical Report GTR SRS-53.

[47] E. J. Jokela, P. M. Dougherty, and T. A. Martin, "Production dynamics of intensively managed loblolly pine stands in the southern United States: a synthesis of seven long-term experiments," Forest Ecology and Management, vol. 192, no. 1, pp. 117-130, 2004.

[48] M. Balboa, R. Rodríguez, J. G. Alvarez et al., "Temporal variations and distribution of carbon stocks in above-ground tree biomass of Pinus radiata and Pinus pinaster pure stands under different silvicultural alternatives," in Proceedings of the International IUFRO Conference on Sustainable hHarvest Scenarios in Forest Management, Tale, the Low Tatras, Slovakia, 2004.

[49] A. Merino, C. Rey, J. Brañas et al., "Biomasa arbórea y acumulación de nutrientes en plantaciones de $P$. radiata en Galicia," Investigación Agraria: Sistemas y Recursos Forestales, vol. 12, no. 2, pp. 85-98, 2003.

[50] J. Goya, C. Pérez, and R. Fernández, "Concentración foliar de nutrientes en plantaciones de diferentes edades de Pinus taeda L. en el norte de Misiones, Argentina," in Proceedings of the 13th Jornadas Técnicas Forestales y Ambientales (UNAM-INTA '08), Eldorado, Misiones, Argentina, 2008.

[51] L. Gonçalves, "Efeito de cultivo mínimo sobre a fertilidade do solo e ciclagem de nutrientes," in Proceedings of the Anais 1 Seminário Sobre Cultivo Mínimo do Solo em Florestas, pp. 4360, CNPFloresta /IPEF/UNESP/SIF/FUPEF, Piracicaba, Brazil, 1995.

[52] S. Little and L. Shainsky, "Distribution of biomass and nutrients in lodgepole Pine/Bitterbrush ecosystems in Central Oregon," USDA Forest Service Research Paper PNWRP 454, 1992.

[53] H. Madgwick and B. Webber, "Nutrient removal in harvesting mature Pinus radiata," New Zealand Journal of Forestry, vol. 32, no. 3, pp. 15-18, 1987.

[54] R. A. Rubilar, H. L. Allen, and D. L. Kelting, "Comparison of biomass and nutrient content equations for successive rotations of loblolly pine plantations on an Upper Coastal Plain Site," Biomass and Bioenergy, vol. 28, no. 6, pp. 548-564, 2005.

[55] F. Poggiani, "Nutrient cycling in Eucalytus and Pinus plantations ecosystems. Silvicultural implications," IPEF, vol. 31, pp. 33-40, 1985.
[56] J. Goya and R. Fernández, "Ciclo de nutrientes en plantaciones de Pinus taeda en el norte de la provincia de Misiones. II estudio de diferentes edades de plantación," Investigación Forestal al Servicio de la Producción II. SAGPyA-Proyecto Forestal de Desarrollo (Buenos Aires, Argentina). pp. 134-143, 2004.

[57] E. Nambiar, "Critical processes in forest nutrition and their importance for management," in Research for Forest Management, J. J. Landsberg and W. Parsons, Eds., pp. 52-72, Research for Forest Management. CSIRO, Australia, 1985.

[58] J. Jorgensen and C. Wells, "Foresters primer in nutrient cycling," Tech. Rep. SE-37, 1986.

[59] G. Ouro, P. Pérez-Batallón, and A. Merino, "Effects of sylvicultural practices on nutrient status in a Pinus radiata plantation: nutrient export by tree removal and nutrient dynamics in decomposing logging residues," Annals of Forest Science, vol. 58, no. 4, pp. 411-422, 2001.

[60] T. G. Baker, "Dry matter, nitrogen, and phosphorus content of litterfall and branchfall in Pinus radiata and Eucalyptus forests," New Zealand Journal of Forestry Science, vol. 13, no. 2, pp. 205-221, 1983.

[61] J. Rodríguez-Calcerrada, S. Mutke, J. Alonso, L. Gil, J. A. Pardos, and I. Aranda, "Influence of overstory density on understory light, soil moisture, and survival of two underplanted oak species in a Mediterranean montane Scots pine forest," Investigacion Agraria Sistemas y Recursos Forestales, vol. 17, no. 1, pp. 31-38, 2008.

[62] W. Harold and J. Hocker, Introducción a la Biología Forestal, México, 1984.

[63] P. Nilsen and L. T. Strand, "Thinning intensity effects on carbon and nitrogen stores and fluxes in a Norway spruce (Picea abies (L.) Karst.) stand after 33 years," Forest Ecology and Management, vol. 256, no. 3, pp. 201-208, 2008.

[64] M. Slodicak, J. Novak, and J. P. Skovsgaard, "Wood production, litter fall and humus accumulation in a Czech thinning experiment in Norway spruce (Picea abies (L.) Karst.)," Forest Ecology and Management, vol. 209, no. 1-2, pp. 157-166, 2005.

[65] J. Bauhus, T. Vor, N. Bartsch, and A. Cowling, "The effects of gaps and liming on forest floor decomposition and soil $\mathrm{C}$ and $\mathrm{N}$ dynamics in a Fagus sylvatica forest," Canadian Journal of Forest Research, vol. 34, no. 3, pp. 509-518, 2004.

[66] G. Montero, C. Ortega, I. Cañellas et al., "Productividad aérea y dinámica de nutrientes en una repoblación de Pinus pinaster sometida a distintos regímenes de claras," Investigación Agraria: Sistemas y Recursos Forestales, vol. 1, pp. 175206, 1999.

[67] L. Vesterdal, M. Dalsgaard, C. Felby, K. Raulund-Rasmussen, and B. B. Jorgensen, "Effects of thinning and soil properties on accumulation of carbon, nitrogen and phosphorus in the forest floor of Norway spruce stands," Forest Ecology and Management, vol. 77, no. 1-3, pp. 1-10, 1995.

[68] M. Begon, M. Townsend, C. John et al., Ecology: From Individuals to Ecosystems, Wiley-Blackwell, 2006.

[69] J. Zerpa, "Understanding forest floor accumulation and nutrient dynamics in a Loblolly pine plantation regenerated with varying forest floor and flash retention," Graduate program in the department of forestry at North Carolina State University under the guidance of Dr. Lee Allen, p. 45, 2005.

[70] A. Wollum and G. Schubert, "Effect of thinning on the foliage and forest floor properties of ponderosa pine stands," Proceedings of the Soil Science Society of America, vol. 39, pp. 968-972, 1975.

[71] A. Escudero and S. Mediavilla, "Dinámica interna de los nutrientes,” Ecosistemas, vol. 12, no. 1, pp. 25-32, 2003. 
[72] R. Rodríguez Soalleiro, M. Balboa, J. González et al., "Efecto de la silvicultura en la extracción de nutrientes a lo largo del turno en plantaciones de tres especies de crecimiento rápido en el norte de España," Investigación Agraria: Sistemas y Recursos Forestales, vol. 13, no. 3, pp. 114-126, 2004.

[73] J. Goya, J. Frangi, G. Denegri et al., "Simulación del impacto de diferentes regímenes de cosecha sobre el capital de nutrientes e indicadores económicos en plantaciones de Eucalyptus grandis del NE de Entre Ríos, Argentina," Augmdomus, vol. 1, pp. 117, 2009.

[74] D. H. Van Lear and P. R. Kapeluck, "Above- and belowstump biomass and nutrient content of a mature loblolly pine plantation," Canadian Journal of Forest Research, vol. 25, no. 2, pp. 361-367, 1995.

[75] R. Worrell and A. Hampson, "The influence of some forest operations on the sustainable management of forest soils-a review," Forestry, vol. 70, no. 1, pp. 61-85, 1997. 

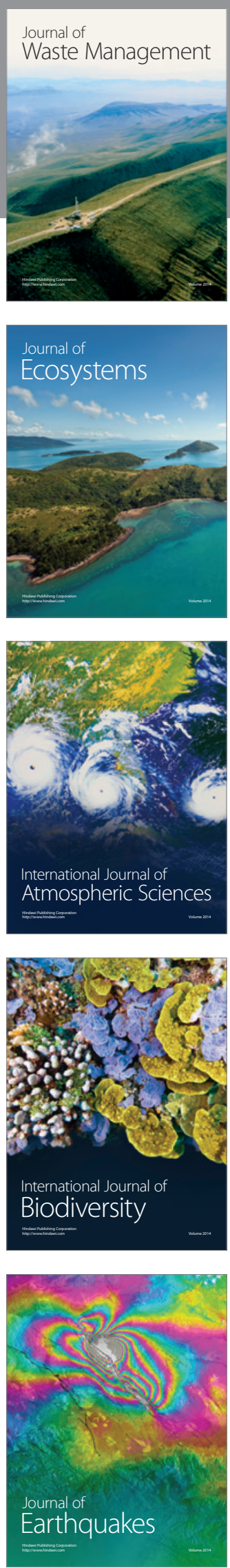
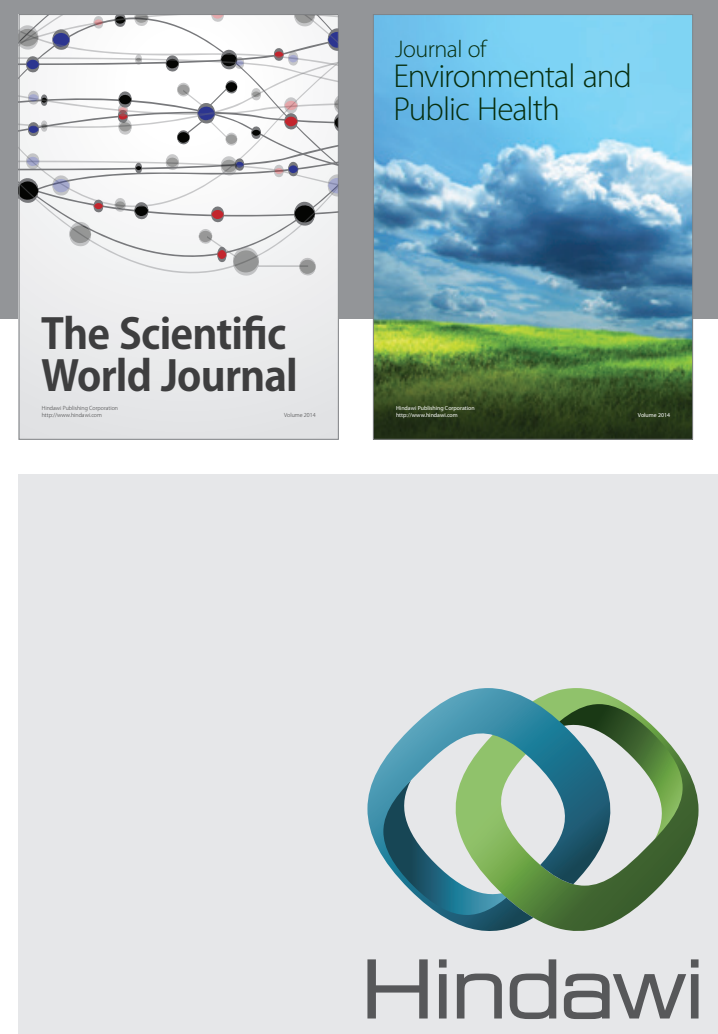

Submit your manuscripts at

http://www.hindawi.com
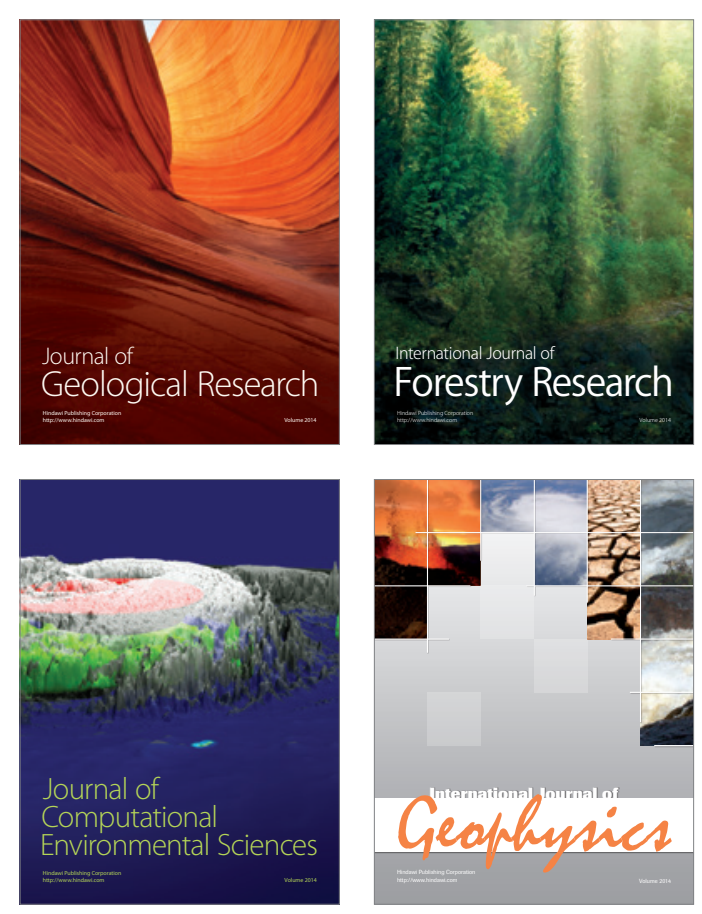
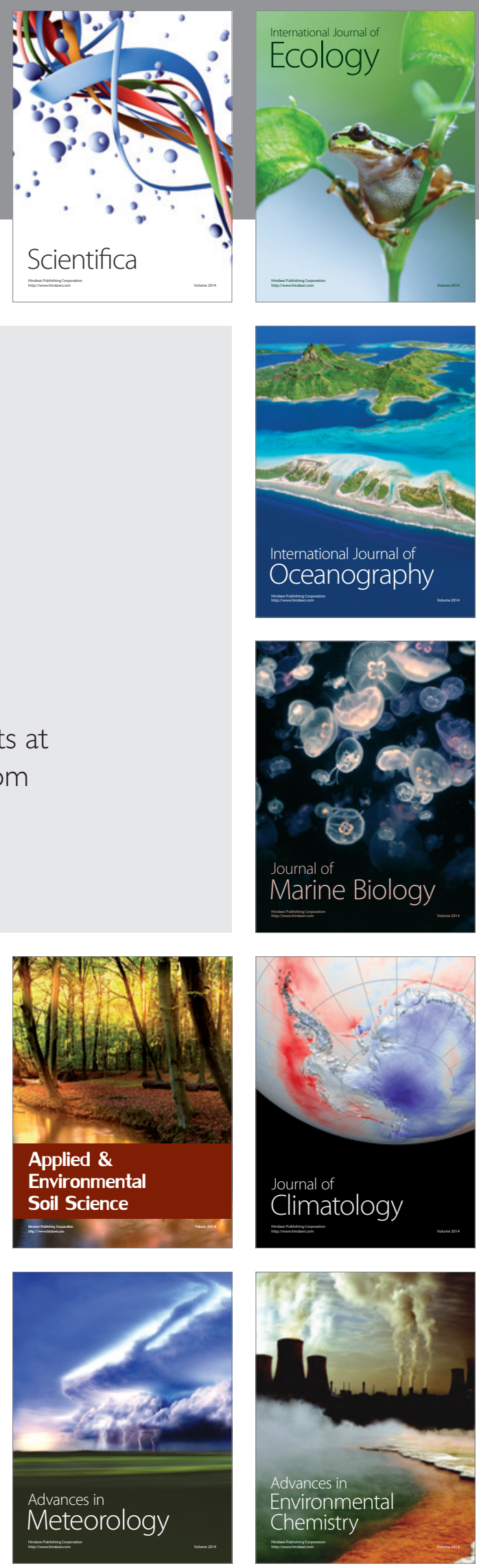